Karthik Balajee Laksham

Vinothkumar Kalidoss

Parthibane Sivanantham

Perumal Murthy Sambath

Manoj Kumar Arunachalam

Palanivel Chinnakali

\title{
HOUSEHOLD BIOCIDE USE AND PERSONAL SAFETY PRACTICES AMONG RURAL POPULATION IN SOUTH INDIA: A COMMUNITY-BASED STUDY
}

\author{
UŻYWANIE BIOCYDÓW W GOSPODARSTWIE DOMOWYM I SPOSOBY ZABEZPIECZANIA SIĘ PRZED NIMI \\ WŚRÓD LUDNOŚCI WIEJSKIEJ W POŁUDNIOWYCH INDIACH - STUDIUM SPOŁECZNOŚCI LOKALNEJ
}

Jawaharlal Institute of Postgraduate Medical Education and Research, Puducherry, India

Department of Preventive and Social Medicine

\begin{abstract}
Background: Household pesticides (biocides) are widely used for the purpose of controlling vector-borne diseases. Exposure to biocides causes various health hazards in human beings. Prevalence of biocide use, storage methods, and personal protection measures while handling biocides are not known among rural households in South India. Material and Methods: A communitybased cross-sectional study was conducted among 416 households in rural Puducherry (union territory). Information on household biocide use, frequency of use, storage and personal safety practices were captured using pretested questionnaire. Continuous variables like age are summarized by mean and standard deviation. Categorical variables like gender, education, a type of a house, biocide usage and related handling practices are summarized as proportions. Results: Majority (85\%) of the households reported presence of at least 1 biocide. Mosquito liquidizer was the most commonly used biocide (45\%) followed by mosquito coil (31\%), ant powder $(30 \%)$ and ant chalk $(20 \%)$. Protection measures against the majority of used biocides were used only in few households and no personal protection measures were used while handling mosquito coil, mat, ant chalk and rat powder. Conclusions: The prevalence of household biocide use is high in the study setting. Storage, handling and post handling practices were not sufficient to protect health. Med Pr 2016;67(5):599-604
\end{abstract}

Key words: safety, India, hygiene, handling practice, biocide use, insecticide

\section{STRESZCZENIE}

Wstęp: Pestycydy używane w gospodarstwach domowych (biocydy) są powszechnie stosowane do zwalczania chorób przenoszonych przez wektory. Narażenie na biocydy jest źródłem różnorodnych zagrożeń dla ludzkiego zdrowia. Brakuje danych dotyczacych rozpowszechnienia używania biocydów, sposobów ich przechowywania i stosowania środków ochrony osobistej w wiejskich gospodarstwach domowych w południowych Indiach. Materiał i metody: Badanie przekrojowe przeprowadzono wśród społeczności lokalnej z 416 wiejskich gospodarstw w Puducherry (terytorium związkowe) w Indiach. Dane dotyczące częstości stosowania biocydów w gospodarstwach domowych, sposobów ich przechowywania i zabezpieczania się przed nimi zebrano z wykorzystaniem wcześniej przetestowanego kwestionariusza. Zmienne ciąłe, takie jak wiek, wyrażono jako średnie i odchylenia standardowe. Zmienne kategoryczne, takie jak płeć, wykształcenie, rodzaj budynku mieszkalnego, użycie biocydów i sposoby ich stosowania, wyrażono jako proporcje. Wyniki: W większości gospodarstw domowych (85\%) stosowano co najmniej 1 środek biobójczy. Najczęściej używanym biocydem był elektrofumigator z płynem przeciw komarom (45\%), następnie spirala przeciw komarom (31\%), proszek przeciw mrówkom (30\%) i kreda przeciw mrówkom (20\%). Przeciwko większości stosowanych biocydów zabezpieczano się tylko w nielicznych gospodarstwach, natomiast żadnych środków ochrony osobistej nie używano podczas stosowania spirali przeciw komarom, elektrofumigatora $\mathrm{z}$ wkładkami przeciw komarom, kredy przeciw mrówkom i proszku przeciw szczurom. Wnioski: Częstość stosowania środków biobójczych w gospodarstwach domowych badanej społeczności była wysoka. Natomiast sposoby przechowywania i używania biocydów, a także postępowania po ich użyciu, nie były wystarczające do ochrony zdrowia. Med. Pr. 2016;67(5):599-604

Słowa kluczowe: bezpieczeństwo, Indie, higiena, praktyka użycia, użycie biocydów, środek owadobójczy

Corresponding author / Autor do korespondencji: Palanivel Chinnakali, Jawaharlal Institute of Postgraduate

Medical Education and Research, Department of Preventive and Social Medicine,

Dhanvantri Nagar, 605006 Puducherry, India, e-mail: palaniccm@gmail.com

Received: August 26, 2015, accepted: July 5, 2016 


\section{INTRODUCTION}

Vector-borne diseases account for $17 \%$ of the estimated global burden of infectious diseases [1]. Vector control is an important strategy used in the control of vectorborne diseases, and chemical control is the most widely used approach in the community [2]. In India, household biocides are used as insecticides, fungicides and rodenticides, out of which insecticides are the most frequently used [3]. Acute exposure to the household biocides causes various health hazards for human beings ranging from allergic asthmatic reactions [4] to gastrointestinal and neurological symptoms [5] and accidental or incidental poisoning [6]. Chronic exposure may lead to neurological symptoms, changes in memory and attention status [7]. Chronic exposure may also lead to cancers like brain tumors [8], acute leukemia [9] and non-Hodgkin's lymphoma [10-12].

The studies on household biocide use in India are limited. A study done in rural Tamil Nadu among 144 households reported that the prevalence of household biocide is as high as $96.5 \%$ [13]. Studying biocide-handling practices in the community will help in educating people regarding safe handling practices. In this study, we aimed at determining the prevalence of the biocide use in households and assessing personal protection measures, post handling practices and storage methods in a rural area of South India.

\section{MATERIAL AND METHODS}

A community-based cross-sectional study was carried out in 2 villages in Union Territory of Puducherry in June 2014. Puducherry, formerly known as Pondicherry, is located in the southern part of India with 4 smallunconnected districts: Pondicherry, Karaikal and Yanam on the coasts of Bay of Bengal, and Mahé on the coast of Arabian Sea. For our study, 2 villages namely Thondamanatham and Thuthipet were selected randomly out of the 4 villages under the Rural Health Centre of a teaching hospital in Pondicherry district. The population of Thondamanatham is about 4000 and Thuthipet is approx. 1000. A substantial proportion of working population is represented by daily wagers in small factories. The literacy rate of Thondamanatham is $82 \%$ and that of Thuthipet is $84 \%$ [14].

Considering $50 \%$ of households are expected to be using biocides (p), with $5 \%$ absolute precision (d) and $\alpha$ error of $5 \%$, the required sample size was 400 . All houses in the selected 2 villages were visited, and personal interviews were conducted with adults above 18 years of age. Information on the socio-demographic profile, pests present in the houses, biocides used, frequency of biocide use, personal protection measures and practices after handling biocides, storage method of biocides was collected during personal interviews using pretested interview schedule. The study was conducted in the month of June 2014.

Operational definition of few products, which contain biocides, is as follows: Mat vaporizers are electric vaporizer systems in which the heating device is available as a plug-in version to be placed somewhere in the room. Liquid vaporizers consist of a heating and a refill in the form of a bottle containing biocide solution. Chalk includes biocides in the form of normal looking chalks. Education of the participants is categorized according to years of schooling as illiterate (no formal education), primary (1-5 years), secondary (6-8 years), high school (9-10 years), higher secondary (11-12 years), and graduate and above.

\section{Ethics}

The procedures followed in this study were in accordance with the ethical standards of the Helsinki Declaration of 1975, as revised in 1983. Informed consent was obtained from the participants before interviewing. Anonymity is maintained regarding the identity of the participants.

\section{Statistics}

Data was single-entered in EpiData Entry (version 3.1, EpiData Association, Denmark) and analyzed in Statistical Package for the Social Sciences (SPSS) (version 16, SPSS Inc., USA). Categorical variables like gender, education, a type of a house, biocide usage and related handling practices are summarized as proportions.

\section{RESULTS}

A total of 416 households were interviewed. Mean (M) age of respondents \pm standard deviation (SD) was $38 \pm 16$ years old. The majority (72\%) of respondents were females and were housewives. About $75 \%$ of the respondents had at least primary education. The majority of the household heads were males (91\%) and $75.5 \%$ had at least primary education. In the majority of the houses (73.6\%), the head of the household was a non-agricultural daily wager and driver (truck or bus drivers). On average, each household had 4 family 
members. Respondents reported presence of different kinds of pests in households like mosquitoes, cockroaches, ants, rats, lizards and spiders. Out of the total households, $96 \%$ of them had at least 1 pest, with an average of 3 pests in a household.

The majority of the households (85.8\%) reported the presence of at least 1 biocide at the time of the interview, with an average of 2 biocides per a household. The usage and safety practices related to biocides are described in the Table 1 . The mosquito liquidizer was the most commonly used biocide (45\%) followed by the mosquito coil (31\%), ant powder (30\%) and ant chalk (20\%). The majority of the biocides were kept 4 feet $(122 \mathrm{~cm})$ above the ground. Except naphthalene and mosquito mat, the other biocides were not kept in the cupboard in the majority of the houses.

Information on persons handling the biocides, storage practices and post handling practices are described in the Table 2. Biocides like the cockroach spray, cock- roach chalk, rat cake and rat powder were handled only by adults. Whereas in some of the households, children were handling biocides like the mosquito coil (4\%), liquidizer (4.4\%), mat (14.3\%), ant chalk (2.4\%) and ant powder $(0.8 \%)$, apart from adults. Personal protective measures like an apron, masks or gloves were practised mainly while handling the cockroach spray (40\%). They were not used when handling biocides like the mosquito coil, mosquito mat, and ant chalk and rat powder.

Post-handling practice like hand washing was practiced in all households after using the rat cake and rat powder. However, hand washing is not always practised while handling the mosquito coil (77\%), liquidizer (68\%) and mat (87.5\%). Mosquito repellants (the mat, coil, liquidizer) and naphthalene balls were predominantly stored in the living room. Whereas the ant powder, ant chalk, rat powder, rat chalk, cockroach chalk and spray were stored in the living room as well as in the kitchen and storeroom.

Table 1. Household biocide usage and safety storage practices among rural households $(\mathrm{N}=416)$ in Puducherry, South India Tabela 1. Używanie biocydów i bezpieczeństwo ich przechowywania w wiejskich gospodarstwach domowych $(\mathrm{N}=416) \mathrm{w}$ Puducherry w południowych Indiach

\begin{tabular}{|c|c|c|c|c|}
\hline \multirow{3}{*}{$\begin{array}{l}\text { Biocide } \\
\text { Biocyd }\end{array}$} & \multirow{3}{*}{$\begin{array}{l}\text { Biocide } \\
\text { usage } \\
\text { Stosowanie } \\
\text { biocydu } \\
{[\mathrm{n}(\%)]}\end{array}$} & \multicolumn{3}{|c|}{$\begin{array}{c}\text { Biocide storage } \\
\text { Przechowywanie biocydu } \\
{[\mathrm{n}(\%)]}\end{array}$} \\
\hline & & \multicolumn{2}{|l|}{$\begin{array}{l}\text { cupboard } \\
\text { szafka }\end{array}$} & \multirow{2}{*}{$\begin{array}{c}\text { at height } \\
\text { above } 4 \text { feet }(122 \mathrm{~cm}) \\
\text { na wysokości } \\
\text { powyżej } 122 \mathrm{~cm}\end{array}$} \\
\hline & & $\begin{array}{c}\text { (under lock and without lock) } \\
\text { ogółem } \\
\text { (zamykana na klucz } \\
\text { i niezamykana) }\end{array}$ & $\begin{array}{c}\text { under lock } \\
\text { zamykana na klucz }\end{array}$ & \\
\hline \multicolumn{5}{|l|}{ Against mosquitos / Przeciw komarom } \\
\hline coil / spirala & $129(31.0)$ & $61(47.2)$ & $11(18.0)$ & $87(67.4)$ \\
\hline liquidizer / elektrofumigator z płynem & $189(45.4)$ & $65(34.3)$ & $9(13.8)$ & $166(87.8)$ \\
\hline naphthalene / naftalen & $31(7.5)$ & $25(80.6)$ & $6(24.0)$ & $26(83.8)$ \\
\hline spray / spray & $20(4.8)$ & $15(75.0)$ & $4(26.6)$ & $18(90.0)$ \\
\hline chalk / kreda & $35(8.4)$ & $23(65.7)$ & $6(26.0)$ & $30(85.7)$ \\
\hline \multicolumn{5}{|l|}{ Against ants / Przeciw mrówkom } \\
\hline powder / proszek & $126(30.3)$ & $62(49.2)$ & $12(19.3)$ & $97(77.0)$ \\
\hline chalk / kreda & $85(20.4)$ & $58(68.2)$ & $7(12.0)$ & $74(87.1)$ \\
\hline \multicolumn{5}{|l|}{ Against rats / Przeciw szczurom } \\
\hline
\end{tabular}


Table 2. Handling of biocides among rural households $(\mathrm{N}=416)$ in Puducherry, South India

Tabela 2. Używanie biocydów w wiejskich gospodarstwach domowych $(\mathrm{N}=416)$ w Puducherry w południowych Indiach

\begin{tabular}{|c|c|c|c|c|c|c|c|c|}
\hline $\begin{array}{l}\text { Biocide } \\
\text { Biocyd }\end{array}$ & \multicolumn{2}{|c|}{$\begin{array}{c}\text { Biocide handlers } \\
\text { Osoby stosujące biocyd } \\
\text { [n (\%)] }\end{array}$} & \multicolumn{2}{|c|}{$\begin{array}{c}\text { Personal protection usage } \\
\text { Stosowanie ochrony osobistej } \\
{[\mathrm{n}(\%)]}\end{array}$} & \multicolumn{2}{|c|}{$\begin{array}{l}\text { Biocide post-handling practices } \\
\text { Praktyki po użyciu biocydu } \\
\text { [n (\%)] }\end{array}$} & \multicolumn{2}{|c|}{$\begin{array}{c}\text { Biocide storage } \\
\text { Przechowywanie biocydu } \\
{[\mathrm{n}(\%)]}\end{array}$} \\
\hline \multicolumn{9}{|l|}{$\begin{array}{l}\text { Against mosquitos / } \\
\text { Przeciw komarom }\end{array}$} \\
\hline $\begin{array}{l}\text { liquidizer / elektrofumigator } \\
\text { z płynem }(\mathrm{N}=189)\end{array}$ & $181(96.5)$ & $8(4.4)$ & $2(1.1)$ & $187(98.9)$ & $130(68.8)$ & $59(31.2)$ & $186(99.5)$ & $1(0.5)$ \\
\hline $\begin{array}{l}\text { mat / elektrofumigator } \\
\mathrm{z} \text { wkładkami }(\mathrm{N}=8)\end{array}$ & $7(85.7)$ & $1(14.3)$ & $0(0.0)$ & $8(100.0)$ & $7(87.5)$ & $1(12.5)$ & $8(100.0)$ & $0(0.0)$ \\
\hline spray / spray $(\mathrm{N}=20)$ & $20(100.0)$ & $0(0.0)$ & $8(40.0)$ & $12(60.0)$ & $18(90.0)$ & $2(10.0)$ & $13(65.0)$ & $7(35.0)$ \\
\hline chalk / kreda $(\mathrm{N}=35)$ & $35(100.0)$ & $0(0.0)$ & $1(2.9)$ & $34(97.1)$ & $34(97.1)$ & $1(2.9)$ & $28(80.0)$ & $7(20.0)$ \\
\hline \multicolumn{9}{|l|}{$\begin{array}{l}\text { Against ants / Przeciw } \\
\text { mrówkom }\end{array}$} \\
\hline powder / proszek $(\mathrm{N}=126)$ & $125(99.2)$ & $1(0.8)$ & $10(7.9)$ & $116(92.1)$ & $122(96.8)$ & $0(3.2)$ & $88(70.4)$ & $37(29.6)$ \\
\hline chalk / kreda $(\mathrm{N}=85)$ & $83(97.6)$ & $2(2.4)$ & $0(0.0)$ & $85(100.0)$ & $82(96.5)$ & $3(3.5)$ & $62(73.8)$ & $22(26.2)$ \\
\hline \multicolumn{9}{|l|}{ Against rats / Przeciw szczurom } \\
\hline cake / kostka $(\mathrm{N}=35)$ & $35(100.0)$ & $0(0.0)$ & $2(5.7)$ & $33(94.3)$ & $35(100.0)$ & $0(0.0)$ & $21(65.6)$ & $11(34.4)$ \\
\hline
\end{tabular}

In the majority of the households, no personal protective measures like gloves/apron or masks were used while using biocides. In all households (100\%), personal protection measures were not used while handling the mosquito coil, mat, ant chalk and rat powder. Clothes were used as face masks by 7 out of 20 participants handling the cockroach spray. Gloves were used by around $5 \%$ of participants handling the liquidizer, naphthalene balls, ant powder, rat cake and cockroach chalk.

The frequency of biocide use in households is shown in the Table 3. Naphthalene balls for the cockroach were mostly used on weekly basis whereas mosquito coils and liquidators were mostly used on a daily basis.

\section{DISCUSSION}

The prevalence of household biocides use is high in the study setting and this finding is similar to another study from India [13]. Mosquito repellents are the most com- monly used household biocides, out of which the liquid vaporizer is most commonly used and is followed by the mosquito coil. But studies done in urban [15] and rural [13] areas of Chennai show that coils are the most commonly used mosquito control measure. The possible reasons for the preference for the liquidizer rather than the coil in this study setting may be due to the perceived adverse effects in using the mosquito coil and the advancement in safety practices with time. The ant powder is the third most commonly used household biocide. Though the prevalence of naphthalene balls is less compared to other studies, their use is dangerous as it is a probable carcinogenic agent [11]. Moreover, naphthalene balls were mostly stored in living rooms, which is an unsafe practice.

Personal protective measures like wearing a cloth mask were used only when handling the cockroach spray. They were not used when handling other biocides. This finding is similar to a study by Rushton et al. in the United Kingdom [16]. 
Table 3. Frequency of biocide usage among rural households $(\mathrm{N}=416)$ in Puducherry, South India

Tabela 3. Częstość używania biocydów w wiejskich gospodarstwach domowych $(\mathrm{N}=416)$ w Puducherry w południowych Indiach

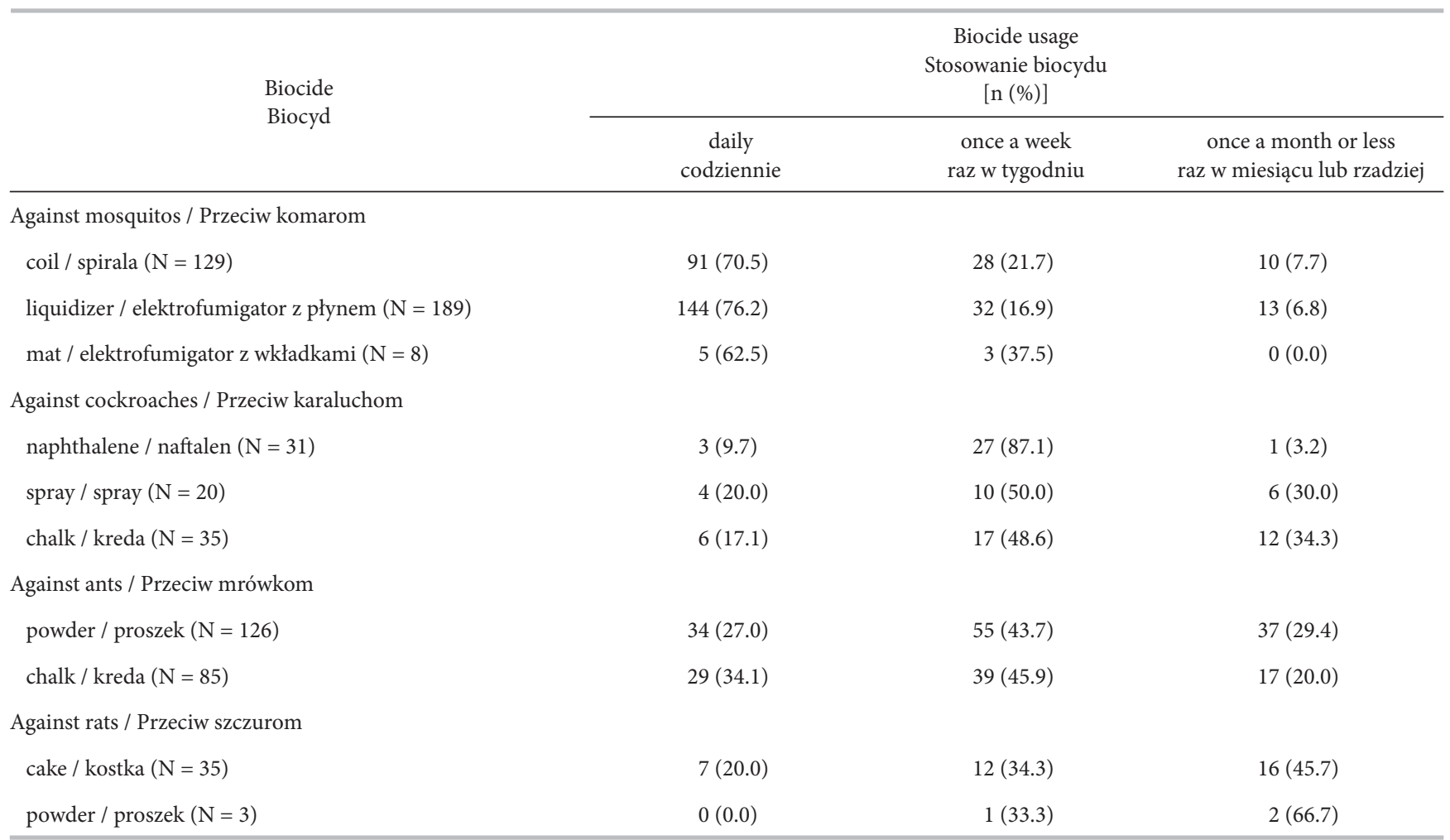

Our study shows that children are handling biocides like the mosquito coil and liquidizer, that contain harmful chemicals like pyrethroids. Menegaux et al. [9] concludes that pyrethroid-based insecticidal shampoo use is associated with the increased risk of acute childhood leukaemia and Ma et al. [10] discusses the potential etiologic role of household biocidal exposures in childhood leukaemia in California. However, children are not handling biocides like the ant powder and rat powder. The majority of the households follow hand-washing practice after handling repellents for the cockroach, rat and ant. But, in 1/3 of the houses, hand-washing practice is not followed when handling the mosquito liquid vaporizer and coils.

Mosquito coils, mats and liquidizers are mostly stored in living rooms. The World Health Organization recommends the storage of biocides in rooms other than living rooms [17]. In 1/3 of the households, the ant chalk, ant powder and rat repellents were mostly stored in the kitchen. In the majority of the houses, biocides were not placed in cupboards and cupboards were also not locked. In $25 \%$ of the houses, the biocides were kept at less than 4 feet $(122 \mathrm{~cm})$ height, which is accessible to children and may lead to accidental or incidental poi- soning in the case children $[6,18]$. This study shows that people in this rural area are not following safe handling practices.

In India, the National Vector Borne Disease Control Programme (NVBDCP) under the Ministry of Health and Family Welfare has developed guidelines for the usage and storage of pesticides as the indoor residual spray and insecticide-treated mosquito nets [19]. But guidelines regarding the household usage and storage of biocides like the mosquito coils, mat and liquidizer, and ant chalk are lacking and have to be framed. The study was conducted in a small geographical area; hence generalizability of the study findings may be limited. The biocide handling practices are collected through self-reporting, which may have introduced desirability bias while reporting safety practices.

\section{CONCLUSIONS}

The use of household biocides was high in this study area. Storage, handling and post handling practices were not optimal. Health education sessions to improve the awareness regarding safe handling of biocides are recommended in this rural area. 


\section{REFERENCES}

1. World Health Organization [Internet]. Geneva: The Organization; 2015 [cited 2015 Jun 19]. About vector-borne diseases. Available from: http://www.who.int/campaigns/world-health-day/2014/vector-borne-diseases/en.

2. World Health Organization. Global insecticide use for vector-borne disease control: A 10-year assessment (2002-2009). 5th ed. Geneva: The Organization; 2011.

3. Abhilash PC, Singh N. Pesticide use and application: An Indian scenario. J Hazard Mater. 2009;165:1-12, http:// dx.doi.org/10.1016/j.jhazmat.2008.10.061.

4. Fagbule D, Ekanem EE. Some environmental risk factors for childhood asthma: A case-control study. Ann Trop Paediatr. 1994;14(1):15-9.

5. Sanborn M, Kerr KJ, Sanin LH, Cole DC, Bassil KL, Vakil C. Non-cancer health effects of pesticides: Systematic review and implications for family doctors. Can Fam Physician. 2007;53(10):1712-20.

6. Banerjee S, Chowdhury AN, Schelling E, Weiss MG. Household survey of pesticide practice, deliberate selfharm, and suicide in the Sundarban region of West Bengal, India. Biomed Res Int. 2013;2013:949076, http:// dx.doi.org/10.1155/2013/949076.

7. Kamel F, Hoppin JA. Association of pesticide exposure with neurologic dysfunction and disease. Environ Health Perspect. 2004;112(9):950-8, http://dx.doi.org/10.1289/ ehp.7135.

8. Pogoda JM, Preston-Martin S. Household pesticides and risk of pediatric brain tumors. Environ Health Perspect. 1997;105(11):1214-20, http://dx.doi.org/10.1289/ ehp.971051214.

9. Menegaux F, Baruchel A, Bertrand Y, Lescoeur B, Leverger G, Nelken B, et al. Household exposure to pesticides and risk of childhood acute leukaemia. Occup Environ Med. 2006;63:131-4, http://dx.doi.org/10.1136/ oem.2005.023036

10. Ma X, Buffler PA, Gunier RB, Dahl G, Smith MT, Reinier $\mathrm{K}$, et al. Critical windows of exposure to household pesticides and risk of childhood leukemia. Environ Health Perspect. 2002;110(9):955-60.

11. World Health Organization. Children's Health and the Environment. WHO training package for the health sector [Internet]. Geneva: The Organization; 2008 [cited 2015 Jun 19]. Available from: http://www.who.int/ceh/ capacity/Pesticides.pdf.

12. Bassil KL, Vakil C, Sanborn M, Cole DC, Kaur JS, Kerr KJ, et al. Cancer health effects of pesticides: Systematic review. Can Fam Physician. 2007;53(10):1704-11.

13. Chitra GA, Kaur P, Bhatnagar T, Manickam P, Murhekar MV. High prevalence of household pesticides and their unsafe use in rural South India. Int J Occup Med Environ Health. 2013;26(2):275-82, http://dx.doi. org/10.2478/s13382-013-0102-6.

14. Registrar General and Census Commissioner [Internet]. New Delhi: The Census; 2010-2011 [cited 2015 Jun 18]. Population enumeration data (final population). Available from: http://www.censusindia.gov.in/2011census/ population_enumeration.html.

15. Janaki M, Jaiganesh D, Rajendran AK. Usage of personal protective measures against mosquito bites among patients attending Fever Clinic in a Tertiary Care Centre. Acad Med J India. 2013;I(1):28-31.

16. Rushton L, Mann V. Pesticide-related illness reported to and diagnosed in primary care: Implications for surveillance of environmental causes of ill-health. BMC Public Health. 2009;9:219, http://dx.doi.org/10.1186/14712458-9-219.

17. World Health Organization. Safe and effective use of household insecticide products. Guide for the production of educational and training materials [Internet]. Geneva: The Organization; 1999 [cited 2015 Jun 18]. Available from: http://whqlibdoc.who.int/hq/1999/WHO_ CDS_CPC_WHOPES_99.1.pdf?ua=1.

18. Boyd DR. Northern exposure: Acute pesticide poisonings in Canada [Internet]. Vancouver: David Suzuki Foundation; 2007 [cited 2015 Jun 18]. Available from: http:// www.davidsuzuki.org/publications/downloads/2007/ DSF-pesticide-poisoning.pdf.

19. National Vector Borne Disease Control Programme. Directorate General of Health Services. Ministry of Health and Family Welfare [Internet]. Delhi: The Programme; 2005 [cited 2015 Jun 18]. Guidelines for vector borne diseases. Available from: http://nvbdcp.gov.in/iec.html.

This work is available in Open Access model and licensed under a Creative Commons Attribution-NonCommercial 3.0 Poland License / Ten utwór jest dostępny w modelu open access na licencji Creative Commons Uznanie autorstwa - Użycie niekomercyjne 3.0 Polska - http://creativecommons.org/ licenses/by-nc/3.0/pl/deed.en. 